5. Husain AN, Siddiqui NH, Stocker JT. Pathology of arrested acinar development in postsurfactant bronchopulmonary dysplasia. Hum Pathol 1998;29(7):710-17. http://dx.doi.org/10.1016/S0046-8177(98)90280-5

6. Coalson JJ. Pathology of new bronchopulmonary dysplasia. Semin Neonatol 2003;8(1):73-81. http://dx.doi.org/10.1016/\$1084-2756(02)00193-8

7. Baraldi E, Filippone $M$, Trevisanuto $D$, Zanardo V, Zacchello F. Pulmonary function until two years of life in infants with bronchopulmonary dysplasia. Am J Respir Crit Care Med 1997;155(1):149-55.

8. Kairamkonda VR, Richardson J, Subhedar N, Bridge PD, Shaw NJ. Lung function measurement in prematurely born preschool children with and without chronic lung disease. J Perinato/ 2008;28(3):199-204. http://dx.doi.org/10.1038/sj.jp.7211911

9. Sadeghi $H$, Lowenthal DB, Dozor AJ. Inspiratory flow limitation in children with bronchopulmonary dysplasia. Pediatr Pulmonol 1998;26(3):167-72. http://dx.doi.org/10.1002/(SICI)1099-0496(199809)26:3<167::AID-PPUL3>3.0.CO;2-I

10. Kennedy JD. Lung function outcome in children of premature birth. J Paediatr Child Health 1999;35:516-21. http://dx.doi.org/10.1046/j.1440-1754.1999.00422.x

11. Baraldi E, Bonetto $G$, Zacchello F, Filippone M. Low exhaled nitric oxide in schoolage children with bronchopulmonary dysplasia and airflow limitation. Am J Respir Crit Care Med 2005;171(1):68-72. http://dx.doi.org/10.1164/rccm.200403-2980C

12. Blayney M, Kerem E, Whyte H, O'Brodovich H. Bronchopulmonary dysplasia: improvement in lung function between 7 and 10 years of age. I Pediatr 1991;118(2):201-06. http://dx.doi.org/10.1016/S0022-3476(05)80483-4

13. Gerhardt $T$, Hehre $D$, Feller R, Reifenberg $L$, Bancalari E. Serial determination of pulmonary function in infants with chronic lung disease. I Pediatr 1987;110(3):448-56. http://dx.doi.org/10.1016/\$0022-3476(87)80516-4

14. Robin B, Kim YJ, Huth J, et al. Pulmonary function in bronchopulmonary dysplasia. Pediatr Pulmonol 2004;37(3):236-42. http://dx.doi.org/10.1002/ppul.10424

15. Gross SJ, lannuzzi DM, Kveselis DA, Anbar RD. Effect of preterm birth on pulmonary function at school age: a prospective controlled study. I Pediatr 1998;133(2):188-92. http://dx.doi.org/10.1016/S0022-3476(98)70219-7

16. Smyth JA, Tabachnik E, Duncan WJ, Reilly BJ, Levison H. Pulmonary function and bronchial hyperreactivity in long-term survivors of bronchopulmonary dysplasia. Pediatrics 1981;68(3):336-40.

17. Doyle LW, Ford GW, Olinsky A, Knoches AM, Callanan C. Bronchopulmonary dysplasia and very low birthweight: lung function at 11 years of age. J Paediatr Child
Health 1996;32(4):339-43. http://dx.doi.org/10.1111/j.1440-1754.1996.tb02566.x

18. Bader D, Ramos AD, Lew CD, Platzker AC, Stabile MW, Keens TG. Childhood sequelae of infant lung disease: exercise and pulmonary function abnormalities after bronchopulmonary dysplasia. J Pediatr 1987;110(5):693-9. http://dx.doi.org/ 10.1016/50022-3476(87)80004-5

19. Parat S, Moriette G, Delaperche MF, Escourrou P, Denjean A, Gaultier C. Long-term pulmonary functional outcome of bronchopulmonary dysplasia and premature birth. Pediatr Pulmonol 1995;20(5):289-96. http://dx.doi.org/10.1002/ ppul. 1950200506

20. Santuz P, Baraldi E, Zaramella P, Filippone M, Zacchello F. Factors limiting exercise performance in long-term survivors of bronchopulmonary dysplasia. Am J Respir Crit Care Med 1995;152(4 Pt 1):1284-9.

21. Hakulinen $A L$, Järvenpää $A L$, Turpeinen $M$, Sovijärvi A. Diffusing capacity of the lung in school-aged children born very preterm, with and without bronchopulmonary dysplasia. Pediatr Pulmonol 1996;21(6):353-60. http://dx.doi.org/10.1002/ (SICI)1099-0496(199606)21:6<353::AID-PPUL2>3.0.CO;2-M

22. Mitchell SH, Teague WG. Reduced gas transfer at rest and during exercise in schoolage survivors of bronchopulmonary dysplasia. Am I Respir Crit Care Med 1998;157(5 Pt 1):1406-12.

23. Northway WH Jr, Moss RB, Carlisle KB, et al. Late pulmonary sequelae of bronchopulmonary dysplasia. N Engl J Med 1990;323(26):1793-9. http://dx.doi.org/10.1056/NEJM199012273232603

24. Doyle LW, Faber B, Callanan C, Freezer N, Ford GW, Davis NM. Bronchopulmonary dysplasia in very low birth weight subjects and lung function in late adolescence. Pediatrics 2006;118(1):108-13. http://dx.doi.org/10.1542/peds.2005-2522

25. Vrijlandt EJ, Gerritsen J, Boezen HM, Grevink RG, Duiverman EJ. Lung function and exercise capacity in young adults born prematurely. Am J Respir Crit Care Med 2006;173(8):890-6. http://dx.doi.org/10.1164/rccm.200507-11400C

26. Halvorsen T, Skadberg BT, Eide GE, Røksund OD, Carlsen KH, Bakke P. Pulmonary outcome in adolescents of extreme preterm birth: a regional cohort study. Acta Paediatr 2004;93(10):1294-300. http://dx.doi.org/10.1111/j.1651-2227.2004. tb02926.x

27. Wong PM, Lees AN, Louw J, et al. Emphysema in young adult survivors of moderate-to-severe bronchopulmonary dysplasia. Eur Respir J 2008;32(2):321-8. http://dx.doi.org/10.1183/09031936.00127107

\title{
COMMENTARY
}

\section{Bronchopulmonary dysplasia: the challenges for primary care}

\author{
*Duncan Keeley ${ }^{a, b}$ \\ a General Practitioner, Thame, Oxfordshire, OX9 3JZ, UK \\ b Policy Lead, PCRS-UK Executive
}

Over the last 40 years there has been enormous progress in the care of children born prematurely. The first systematic description of bronchopulmonary dysplasia (BPD) - a syndrome of chronic lung damage in premature babies receiving mechanical ventilation and high concentrations of oxygen - was published in 1967; the mean gestation was 34 weeks, the mean birthweight $2.2 \mathrm{~kg}$, and the mortality was $67 \%$. Improvements in neonatal care, including better methods of ventilation and the use of exogenous surfactant in the treatment of hyaline membrane disease, have resulted in the survival of infants of progressively lower birthweight so that now the majority of infants affected by BPD were born weighing less than $1 \mathrm{~kg} .{ }^{1}$ The pattern of pathological changes has evolved, with fewer changes in airway epithelium and less fibroproliferative change, but prominent impairment of alveolar and vascular development. This "new" pattern of BPD may occur in infants who have needed relatively

* Corresponding author: Dr Duncan Keeley, The Health Centre, East Street, Thame, Oxon, OX9 3JZ, UK

Tel: +44 (0)1844 261066 Fax +44 (0)1844 260347 E-mail: auby17@dsl.pipex.com 
little ventilatory support. ${ }^{2}$ Infants with BPD may have protracted oxygen dependence. Diffuse abnormality of chest radiographs is common but correlates poorly with the degree of lung function abnormality.

This review article by Hayes et al. ${ }^{3}$ summarises the evidence of continuing abnormalities in lung function affecting infants with BPD surviving into childhood and adulthood. At all ages studied, lung function abnormalities - including reductions in FEV 1 and expiratory flow, and increased rates of bronchial hyperreactivity and airway obstruction - were more prevalent in children and young adults who had had BPD than in children born at term or children born prematurely who had not developed BPD.

What are the implications of these findings for clinicians in primary care? Children discharged from premature baby units who remain oxygen dependent usually receive continued supervision in the community from specialist community paediatric nursing services together with easy access to hospital paediatric teams, but primary care clinicians need to be fully aware of the situation and involved in sharing care. The practicalities of caring for a premature infant both before and after discharge from hospital can put enormous strain on parents and siblings, and their health and emotional needs must be remembered.

Knowledge of the child when well facilitates clinical assessment of intercurrent illness. Clinical deterioration may occur in the context of acute infections or due to the development of reactive airway disease or pulmonary hypertension. Infants with BPD are at high risk of re-admission to hospital with respiratory complications in the first two years of life, especially in the context of RSV infection. The prophylactic use of monoclonal antibody to RSV (palivizumab) has been advocated, and may be cost-effective. ${ }^{4}$ Thresholds for face-toface clinical assessment of respiratory illness - including pulse oximetry - and for hospital-admission need to be lower in children with BPD.

In addition, it is important that primary care clinical record summaries should include important perinatal details, including the weight and gestation at birth of infants born prematurely. A diagnosis of BPD should be separately recorded. Completion of routine immunisations is important.

In later childhood and adult life primary care clinicians should be aware of the perinatal history and of the increased likelihood of respiratory disorders. Spirometry with reversibility testing should be performed in those with overt recurrent respiratory symptoms, ${ }^{5}$ and referral should be considered if there has been no recent specialist respiratory assessment. Influenza immunisation should be offered. If asthma is diagnosed it should be managed according to recognised guidelines. Avoidance of tobacco smoking is very important, and every effort should be made to achieve smoking cessation in patients with a history of BPD who do smoke.

It is recognised that assessment of the effects of management practices in the neonatal respiratory care of premature infants should preferably include determination of clinical and physiological outcomes in the medium to long term, but there are no comprehensive follow-up studies into adult life. In an earlier review, Kinsella and colleagues argued that, "More research is needed to determine the long-term respiratory course of premature neonates, with or without severe BPD, and their relative contribution to the growing adult population with chronic obstructive pulmonary disease." ${ }^{\prime 1}$ Better recording of basic neonatal histories in primary care would help facilitate such enquiries as well as improving the care of individuals.

\section{Conflict of interests}

None.

\section{References}

1. Kinsella JP, Greenough A, Abman S. Bronchopulmonary dysplasia. Lancet 2006; 367:1421-31. http://dx.doi.org/10.1016/S0140-6736(06)68615-7

2. Jobe AJ. The new BPD: an arrest of lung development. Pediatr Res 1999; 46(6):641-3. http://dx.doi.org/10.1203/00006450-199912000-00001

3. Hayes Jr D, Meadows Jr JT, Murphy BS, Feola DJ, Shook LA, Ballard HO. Pulmonary function outcomes in bronchopulmonary dysplasia through childhood and into adulthood: implications for primary care. Prim Care Respir J 2011;20(2):128-33. http://dx.doi.org/10.4104/pcrj.2011.00002.

4. Nuijten MJ, Wittenberg W, Lebmeier M. Cost effectiveness of palivizumab for respiratory syncytial virus prophylaxis in high-risk children: a UK analysis. Pharmacoeconomics 2007;25(1):55-71. http://dx.doi.org/10.2165/00019053200725010-00006

5: Lum S, Kirkby J, Welsh L, Marlow N, Hennessy E, Stocks J. Nature and severity of lung function abnormalities in extremely preterm children at $11 \mathrm{y}$. Eur Respir J 2010 Oct 14. [Epub ahead of print] PubMed PMID: 20947682

Commissioned article; not externally peer-reviewed; accepted 26th April 2011; online 20th May 2011

C 2011 Primary Care Respiratory Society UK. All rights reserved. D Keeley. Prim Care Respir J 2011; 20(2): 133-134.

doi:10.4104/pcrj.2011.00049

\section{Available online at http://www.thepcrj.org}

